\title{
Mechanisms underlying persistent activity in a model PFC microcircuit
}

\author{
Athanasia Papoutsi*, Kyriaki Sidiropoulou and Panayiota Poirazi
}

\author{
Address: Institute of Molecular Biology and Biotechnology (IMBB), Foundation for Research and Technology-Hellas (FORTH), Crete, Greece \\ Email: Athanasia Papoutsi* - athpapoutsi@yahoo.gr \\ * Corresponding author
}

from Eighteenth Annual Computational Neuroscience Meeting: CNS*2009

Berlin, Germany. 18-23 July 2009

Published: 13 July 2009

BMC Neuroscience 2009, 10(Suppl I):P42 doi:I0.II86/I47I-2202-I0-SI-P42

This abstract is available from: http://www.biomedcentral.com/I47I-2202/I0/SI/P42

(c) 2009 Papoutsi et al; licensee BioMed Central Ltd.

PFC neurons provide the means to establish behavioral continuity over time by sustaining their firing rate throughout the delay period during working memory tasks. So far, synaptic reverberation has been proposed to underlie the persistent activity, through recurrent excitation, within a homogenous network [1]. However, electrophysiological data suggest that the pyramidal network that supports this activity exhibits biophysical heterogeneity [2]. The goal of this study is to incorporate such biophysical data in a compartmental network model of layer V PFC neurons and investigate the role of cellular mechanisms in supporting persistent activity. Toward this goal, we developed a microcircuit containing both pyramidal and interneuron models of layer V PFC cells. The pyramidal neuron model is implemented in the NEURON simulation environment [3] and is morphologically simplified; it includes modeling equations for 15 types of ionic mechanisms, known to be present in these neurons and is validated against experimental data [4]. The interneuron model is a previously published basket-type fast spiking neocortical interneuron [5]. The microcircuit contains a single interneuron and four pyramidal cells and is fully connected through recurrent connections. The connectivity properties of the network (type/location of synapses) were based on experimental anatomical and electrophysiological data [6], in an effort to simulate a microcolumn of layer $\mathrm{V}$ pyramidal neurons in the PFC. The microcircuit was used to investigate the stimulation protocol as well as the biophysical makeup required for the sustained firing. The specific contribution of both intrinsic (the calcium activated non-selective cation (CAN) current) and synaptic (the NMDA receptor) mechanisms that have previously been suggested to partake a role in persistent firing $[4,7]$ was examined. Simulations revealed that persistent activity at physiological frequencies could emerge in the microcircuit throughout a physiological range of NMDA-to-AMPA current ratios [8]. Furthermore, activation of the CAN current modulated the properties (firing frequency distribution) of this sustained activity. In summary, preliminary results show that our microcircuit is capable of supporting persistent activity resulting from the interaction of intrinsic ionic mechanisms and synaptic input. We further suggest that intrinsic mechanisms of pyramidal neurons may counteract the limiting effect of heterogeneity in PFC networks. On going simulations aim to dissect the roles of CAN and NMDA mechanisms in the emergence and maintenance of persistent activity in layer $\mathrm{V}$ of PFC, as well as the ability of a second stimulus to modulate the properties of persistent activity.

\section{Acknowledgements}

This work was supported by EMBO Young Investigator Program (PP), an IKY postdoctoral fellowship (KS), and Maria Michail Manasaki-University of Crete scholarship (AP). 


\section{References}

I. Renart A, Song P, Wang XJ: Robust spatial working memory through homeostatic synaptic scaling in heterogeneous cortical networks. Neuron 2003, 38:473-485.

2. Wang Y, Markram H, Goodman PH, Berger TK, Ma J, Goldman-Rakic PS: Heterogeneity in the pyramidal network of the medial prefrontal cortex. Nature Neuroscience 2006, 9:534-542.

3. Hines ML, Carnevale NT: The NEURON simulation environment. Neural Comput 1997, 9:II79-1209.

4. Sidiropoulou K, Lu FM, Fowler MA, Xiao R, Phillips C, Ozkan ED, Zhu MX, White FJ, Cooper DC: Dopamine modulates an mGluR5mediated depolarization underlying prefrontal persistent activity. Nature Neuroscience 2009, I 2:190-199.

5. Durstewitz D, Seamans JK, Sejnowski TJ: Dopamine-mediated stabilization of delay-period activity in a network model of prefrontal cortex. INeurophysiology 2000, 83:1733-I750.

6. Thomson AM, Deuchars J: Synaptic interactions in neocortical local circuits: dual intracellular recordings in vitro. Cerebral Cortex 1997, 7:510-522

7. Compte A, Brunel N, Goldman-Rakic PS, Wang XJ: Synaptic mechanisms and network dynamics underlying spatial working memory in a cortical network model. Cereb Cortex 2000, 10:910-923.

8. Myme $\mathrm{Cl}$, Sugino K, Turrigiano GG, Nelson SB: The NMDA-toAMPA ratio at synapses onto layer 2/3 pyramidal neurons is conserved across prefrontal and visual cortices. I Neurophysiology 2003, 90:771-779.

Publish with Bio Med Central and every scientist can read your work free of charge

"BioMed Central will be the most significant development for disseminating the results of biomedical research in our lifetime. "

Sir Paul Nurse, Cancer Research UK

Your research papers will be:

- available free of charge to the entire biomedical community

- peer reviewed and published immediately upon acceptance

- cited in PubMed and archived on PubMed Central

- yours - you keep the copyright

Submit your manuscript here:

http://www.biomedcentral.com/info/publishing_adv.asp 